\title{
Investigating the effects of personal entrepreneurial characteristics
}

\author{
Masoumeh Sadat Abtahi, Mohammadreza Karamipour and Kobra Abbasi
}

Department of Humanities, Research and science Zanjan branch, Islamic Azad University, Zanjan, Iran

\begin{tabular}{|c|c|}
\hline C H RON I C L E & A B S T RACT \\
\hline $\begin{array}{l}\text { Article history: } \\
\text { Received October 28, } 2013 \\
\text { Received in revised format } \\
25 \text { November } 2013 \\
\text { Accepted } 22 \text { January } 2014 \\
\text { Available online } \\
\text { January } 252014 \\
\text { Keywords: } \\
\text { Personal entrepreneurial } \\
\text { characteristics } \\
\text { Idea fluency } \\
\text { Need to succeed } \\
\text { Praamatism }\end{array}$ & $\begin{array}{l}\text { This paper presents an empirical investigation to study the impacts of personal entrepreneurial } \\
\text { characteristics including "Need to succeed", "Idea fluency" and "Pragmatism" among students } \\
\text { who were enrolled in different fields at Islamic Azad University of Zanjan, Iran. Using a } \\
\text { standard questionnaire, which is modified for Iranian culture, the study measures the effects of } \\
\text { three factors. The results of Kolmogorov-Smirnov indicate that all three variables of the survey } \\
\text { were normally distributed. The results of t-student test for "Need to succeed" is equal to } 28.623 \\
\text { with df = } 349 \text { and Sig. = } 0.000 \text {, which is statistically significant. In addition, t-student test for } \\
\text { "Idea fluency" is equal to } 16.124 \text { with df = } 349 \text { and Sig. = } 0.000 \text {, which is also statistically } \\
\text { significant. Finally, the results of t-student test for "Pragmatism" is equal to } 31.255 \text { with df = } \\
349 \text { and Sig. = 0.000, which is statistically significant. The findings indicate that the } \\
\text { participants hold relatively high level of personal entrepreneurial characteristics. }\end{array}$ \\
\hline
\end{tabular}

\section{Introduction}

During the past few years, there have been many studies on investigating entrepreneurship and the characteristics of the entrepreneurial personality (Brockhaus \& Horwitz, 1986; Uru et al., 2012). Littunen (2000) investigated the characteristics of the entrepreneurial personality and the impacts of changes in the entrepreneur's personal relationships. The author reported that becoming an entrepreneur and acting as an entrepreneur were both perspectives of the entrepreneur's learning process, which in turn maintained an important impact on the personality characteristics of the entrepreneur. They also reported that as the number of co-operative partners decreased, control by powerful others also decreased, and that, since the start-up phase, entrepreneurs whose personal relations had increased also demonstrated a clear increase in mastery. Lee and Tsang (2001) investigated the impacts of entrepreneurial personality, background and network activities on venture growth among 168 Chinese entrepreneurs in Singapore. They reported that experience, networking activities, and numbers of partners as well as internal locus of control and need for achievement had

E-mail addresses: m.abtahi2008@gmail.com (M. S. Abtahi) 
positive effect on venture growth. Two other personality traits, self-reliance and extroversion had negative effect on number of partners and positive impact on networking activities, respectively. The effect of education on venture growth, however, was moderated by firm size, positive for larger firms and negative for smaller firms. They also indicated that among all the factors, an entrepreneur's industrial and managerial experience was the dominating factor influencing venture growth.

Tu et al. (2012) investigated the joint effects of personal and relationships characteristics on microentrepreneurial success. The study attempted to combine the personal characteristics with the relationship characteristics of micro-entrepreneurs to develop a theoretical structure of antecedents influencing on the micro-entrepreneurs success and deepen our understanding of microentrepreneurial academic research and practical implication.

Nejatbakhsh Esfahani and Shirazi Pour (2013) studied the impacts of entrepreneurial characteristic of public and private Tehran school principals on evaluation of innovativeness. Altinay et al. (2012) investigated the effect of family tradition and psychological traits on the entrepreneurial intention of hospitality students. The study was predicated on the necessity to consider both socio-demographic variables and especially family background and personality traits and emphasized on the relative importance of taking a more holistic approach when researching the factors that influence entrepreneurial intention. Ravasi and Turati (2005) reported some findings from a comparative study of factors influencing the learning process, which underlies entrepreneurial innovation, as entrepreneurs move from an initial intuition to a well-developed new product or service. Their results through comparative study highlighted the self-reinforcing impact of prior related knowledge, perceived incentives and the degree of control on the allocation of entrepreneurs' limited time, attention and resources. They proposed an interpretative model, which indicated that innovation in entrepreneurial ventures rests on self-reinforcing learning cycles.

\section{The proposed study}

This paper presents an empirical investigation to study the impacts of personal entrepreneurial characteristics including "Need to succeed", "Idea fluency" and "Pragmatism" among students who were enrolled in different fields at Islamic Azad University of Zanjan, Iran. The sample size is calculated as follows,

$$
n=\frac{N \times z_{\alpha / 2}^{2} \times p \times q}{\varepsilon^{2} \times(N-1)+z_{\alpha / 2}^{2} \times p \times q},
$$

where $N$ is the population size, $p=1-q$ represents the yes/no categories, $z_{\alpha / 2}$ is CDF of normal distribution and finally $\varepsilon$ is the error term. Since we have $p=0.5, z_{\alpha / 2}=1.96$ and $N=11000$, the number of sample size is calculated as $n=350$. The study designs the questionnaire in Likert scale and distributes it among 400 students, randomly. Cronbach alpha has been calculated as 0.86, which is well above the minimum acceptable level of 0.70 . The proposed study has applied KolmogorovSmirnov in order to understand whether the data are normally distributed or not and Table 1 shows details of our findings.

\section{Table 1}

The summary of Kolmogorov-Smirnov

\begin{tabular}{lccl}
\hline Variable & Statistics & Sig. & Result \\
\hline Need to succeed & 0.382 & 0.000 & Normally distributed \\
Idea fluency & 0.228 & 0.000 & Normally distributed \\
Pragmatism & 0.112 & 0.000 & Normally distributed \\
\hline
\end{tabular}


Based on the results of Table 1, we can confirm that all three components of the survey are normally distributed. Therefore, we can use parametric tests to examine various hypotheses of the survey.

\section{The results}

In this section, we present details of our findings on testing three hypotheses of the survey.

3.1. The effect of "Need to succeed"

Need to succeed is the first variable of this survey, which measures how motivated they are to develop a new idea and become an entrepreneur. Table 2 presents the summary of some statistical observation on testing "Need to succeed".

\section{Table 2}

The summary of statistical observation on "Need to succeed"

\begin{tabular}{lcccccc}
\hline & & & & & \multicolumn{2}{c}{ Mean-difference } \\
\cline { 6 - 7 } Variable & Mean & Std. Dev. & t-student & Sig. & Min & Max \\
\hline Need to succeed & 37.81 & 6.74 & 28.623 & 0.000 & 9.6 & 10.30 \\
\hline
\end{tabular}

As we can observe from the results of Table 2, "Need to succeed", is statistically meaningful when the level of significance is one percent. Therefore, we can conclude that the people how participated in our survey are highly motivated to act as entrepreneur.

\subsection{The effect of "Idea fluency"}

Idea fluency is the second component of this survey, which measures how much they are familiar with details of their idea. Table 3 shows the summary of some statistical observation on testing "Idea fluency”.

Table 3

The summary of statistical observation on "Idea fluency"

\begin{tabular}{lcccccc}
\hline & & & & & \multicolumn{2}{c}{ Mean-difference } \\
\cline { 6 - 7 } Variable & Mean & Std. Dev. & t-student & Sig. & Min & Max \\
\hline Idea fluency & 38.29 & 6.71 & 16.124 & 0.000 & 5.08 & 5.74 \\
\hline
\end{tabular}

As we can observe from the results of Table 3, "Idea fluency", is statistically meaningful when the level of significance is one percent. Therefore, we can conclude that the people how participated in our survey have good potentials to develop an idea and act as entrepreneur.

\subsection{The effect of "Pragmatism"}

Pragmatism is the last variable of this survey, which measures how pragmatic they are to develop a new idea and become an entrepreneur. Table 4 demonstrates the summary of some statistical observation on testing "Pragmatism".

\section{Table 4}

The summary of statistical observation on "Pragmatism"

\begin{tabular}{lcccccc}
\hline & & & & & \multicolumn{2}{c}{ Mean-difference } \\
\cline { 5 - 7 } Variable & Mean & Std. Dev. & t-student & Sig. & Min & Max \\
\hline Pragmatism & 26.90 & 4.13 & 31.255 & 0.000 & 6.46 & 6.89 \\
\hline
\end{tabular}


As we can observe from the results of Table 4, "Pragmatism", is statistically meaningful when the level of significance is one percent. Therefore, we can conclude that the people how participated in our survey are highly pragmatic to act as entrepreneur.

\section{Conclusion}

In this paper, we have presented an empirical investigation to measure the effects of personal entrepreneurial characteristics among students who were enrolled in one of Islamic Azad Universities in province of Zanjan, Iran. The study has adopted a standard questionnaire in Likert scale and distributed it among some randomly selected students and using t-student test, the study has confirmed that students have good potentials to act as entrepreneur.

\section{Acknowledgement}

The authors would like to thank the anonymous referees for constructive comments on earlier version of this paper.

\section{References}

Altinay, L., Madanoglu, M., Daniele, R., \& Lashley, C. (2012). The influence of family tradition and psychological traits on entrepreneurial intention. International Journal of Hospitality Management, 31(2), 489-499

Brockhaus, R. H., \& Horwitz, P. S. (1986). The psychology of the entrepreneur. Entrepreneurship: Critical Perspectives on Business and Management, 2, 260-283.

Lee, D. Y., \& Tsang, E. W. (2001). The effects of entrepreneurial personality, background and network activities on venture growth. Journal of management studies, 38(4), 583-602.

Littunen, H. (2000). Entrepreneurship and the characteristics of the entrepreneurial personality. International Journal of Entrepreneurial Behaviour \& Research, 6(6), 295-310.

Nejatbakhsh Esfahani, A., \& Shirazi Pour, M. (2013). Effects of entrepreneurial characteristic of public and private Tehran school principals on evaluation of innovativeness. Procedia - Social and Behavioral Sciences, 93, 1736-1743.

Ravasi, D., \& Turati, C. (2005). Exploring entrepreneurial learning: a comparative study of technology development projects. Journal of Business Venturing, 20(1), 137-164

Tu, C., Hwang, S.N., Chen, J.S., \& Chang, F.Y. (2012). The joint effects of personal and relationships characteristics on micro-entrepreneurial success. Procedia Economics and Finance, 4, 365-372.

Uru, F. O., Caliskan, S. C., Atam, O., \& Aksu, M. (2011). How much entrepreneurial characteristics matter in strategic decision-making. Procedia - Social and Behavioral Sciences, 24, 538-562. 